\title{
Anti-Inflammation Potentials of Ageratum Conyzoides against Crude Oil-Induced Inflammation and Sperm DNA Damage in Male Wistar Rats
}

Ita, S. O. ${ }^{*}$, Francis, E. E. ${ }^{2}$, Eda, A. U. ${ }^{3}$, Francis, U. E. ${ }^{4}$, Abia, E. R. ${ }^{5}$,

\author{
${ }^{1}$ Department of Physiology, Faculty of Basic Medical Sciences, College of Health Sciences, University of Uyo, Uyo, Akwa Ibom State, \\ Nigeria \\ ${ }^{2}$ Department of Physiology, Faculty of Basic Medical Sciences, College of Health Sciences, University of Uyo, Uyo, Akwa Ibom State, \\ Nigeria \\ ${ }^{3}$ Department of Physiology, Faculty of Basic Medical Sciences, College of Health Sciences, University of Uyo, Uyo, Akwa Ibom State, \\ Nigeria \\ ${ }^{4}$ Department of Physiology, Faculty of Basic Medical Sciences, College of Health Sciences, University of Uyo, Uyo, Akwa Ibom State, \\ Nigeria \\ ${ }^{5}$ Department of Physiology, Faculty of Basic Medical Sciences, College of Health Sciences, University of Uyo, Uyo, Akwa Ibom State, \\ Nigeria
}

DOI: https://doi.org/10.15520/jcmro.v2i01.115

Accepted 01-01-2019; Received 24-12-2018; Publish Online 02-01-2019

\section{Reviewed By: Azzaa \\ Ali Hussain \\ Department: \\ Department of \\ Histology, Faculty of Medicine, Sudan.}

\begin{abstract}
Sperm carry the necessary genome materials require for procreation in the deoxyribonucleic acid (DNA), and the integrity of this DNA is cardinal to the survival and function of spermatozoa. This integrity can be compromised due to the vulnerability of sperm cell which could impact negatively on male reproductive health. Forty male Wistar rats (119-128g body weight) were divided into eight groups of five rats each. Group I served as the control and were oral gavaged $3 \mathrm{ml} / \mathrm{kg}$ of normal saline; groups II-IV gavaged $374.17 \mathrm{mg} / \mathrm{kg}, 748.33 \mathrm{mg} / \mathrm{kg}$ and $1122.50 \mathrm{mg} / \mathrm{kg}$ body weight of the extract of Ageratum conyzoides respectively. Group V was gavaged $3 \mathrm{ml} / \mathrm{kg}$ body weight of Nigerian Bonnylight crude oil (NBLCO). Groups VI-VIII was co-administered the aforementioned doses of the extract of Ageratum conyzoides with $3 \mathrm{ml} / \mathrm{kg}$ body weight of NBLCO respectively. The results showed that NBLCO significantly increased DNA damages, elevated C-reactive protein and interleukin-6 levels compared to the control and extract of Ageratum conyzoides groups $(\mathrm{p}<0.05)$. The co-administration of ethanol leaf-extracts of Ageratum conyzoides with NBLCO significantly reversed these trends $(\mathrm{p}<0.05)$. While the NBLCO significantly decreased platelet count and percentage of the circulating neutrophils compared to the control and extract treated groups $(\mathrm{p}<0.05)$, it significantly elevated the total white blood cell count $(\mathrm{p}<0.05)$. But the co-administration of the extract with NBLCO significantly increased platelet count as well as the percentage of circulating neutrophils $(\mathrm{p}<0.05)$. It is concluded that the co-administration of ethanol leaf-extract of Ageratum conyzoides with NBLCO can ameliorate sperm DNA.
\end{abstract}

Key words: Ageratum conyzoides-rats-crude oil-oxidation-inflammationspermatozoa 


\section{Anti-Inflammation Potentials of Ageratum Conyzoides against Crude Oil-Induced Inflammation and Sperm DNA Damage in Male Wistar Rats

ductive function targeted at the male germ cellsColborn $\mathrm{T}$, Vom Saal FS, Soto AM (1993). Developmental effects of endocrine disrupting chemicals in wildlife and humans. Environ Health Perspect. 101:378-384.Colborn T, Vom Saal FS, Soto AM (1993). Developmental effects of endocrine disrupting chemicals in wildlife and humans. Environ Health Perspect. 101:378-384.Colborn T, Vom Saal FS, Soto AM (1993). Developmental effects of endocrine disrupting chemicals in wildlife and humans. Environ Health Perspect. 101:378-384.Colborn T, Vom Saal FS, Soto AM (1993). Developmental effects of endocrine disrupting chemicals in wildlife and humans. Environ Health Perspect. 101:378384. [1] (Colborn et al., 1993; Golden

et al., 1999; Moline et al., 2000). This appeared to put male reproductive health under threat because of the ubiquitous nature of crude oil during spillages into bodies of water particularly in areas with increase activities of crude oil exploration and exploitation. Crude petroleum contain polycyclic aromatic hydrocarbons (PAHs) as the major chemical constituent, which are biologically active agents with potentials of causing injuries to cells, tissues and organs of the body as endocrine disruptors, oxidation of biological lipids, genetoxic, cytotoxic, generation of oxidant radicals and apoptotic activities. Exposure to PAH containing chemicals such as crude petroleum could impact adversely on human spermatogenesis; sperm function as well as damages to sperm DNA and chromatin to manifest infertility.

The male germ cells (spermatozoa) carry the necessary genomic materials required for procreation in the DNA which makes the sperm cell the primary target for injuries upon assault. Such that injury of any form to the sperm DNA can have adverse consequences on spermatogenesis and function of sperm, as maintenance of sperm DNA integrity is crucial to procreation and male reproductive health [2] (Evans, 1996; Aitken et al., 1998).

Reproductive toxicology studies have focused more on analysis of the conventional semen parameters of sperm count, motility and morphology with the searchlight on the capacity of sperm to fertilize an egg. Such evaluation can only provide insight into the function of the testis (WHO, 1999), and with little or no information on the genomic material of sperm DNA [3] (Morris et al., 2002). The integrity of the genomic sperm DNA is cardinal to the transmission of genetic information during spermatogenesis and indeed the entire reproductive processes. Damage to the genomic DNA coupled with disruption of other sperm parameters in male may ultimately affect male fertility [4] (Evenson et al., 2002; Agarwal and Said, 2003). Many environmental and genetic factors have been implicated in conditions of poor sperm function as related to male infertility (WHO, 1992).

Available facts in literature have shown that exposure to various environmental insults over the past decades have contributed immensely to infertility on accounts of declining trend in the sperm count of human and even wildlife [5] [6] [7] [8] (Lyons et al., 1999; Izegbu et al., 2005; Shittu et al., 2007., Shittu et al., 2008). In the Niger
Delta region of Nigeria, the rapid increase activities in the oil industry, leakages of diverse sources, spillages and wide varieties of pollution, humans and wildlife are at the risk of continuous exposure to these toxicants. Such cytotoxic and biochemical derangements associated with ingestion of crude oil polluted marine extractions like fish, shrimps, prawns, crayfish, oyster etc. [9] (Nwaokwoala and George, 2000), with spectrum of toxic effects have been reported [10] (Yadau and Seth, 2001). Spermatozoa are reported to be much more susceptible to environmental toxicants due primarily to the inability of the spermatozoa to repair their damaged DNA as they lack the enzymatic machinery to do so [11] (Anderson et al., 1997). Polycyclic aromatic hydrocarbons content of crude petroleum appeared to be the main executor of the hazardous effects of petroleum and its refined products on the body. Reports showed PAHs to derive their genetoxic and cancernogenic potency from their abilities to attack DNA which may be a potential source of DNA damage in sperm [12] (Zenzes et al., 1999).

The probability that crude petroleum induce inflammation in the body is very high as damages in the body are mediated through induction of oxidative stress and lipid peroxidation [13] (Ita et al., 2018). Inflammation is the body's own mechanism of protesting against insults of varied sources, but unrestricted inflammatory process can by itself cause collateral harm to the body. The association of inflammation with oxidative stress has been demonstrated to be harmful to sperm where excessive ROS is generated to cause damages sperm DNA and induce apoptosis [14] [15] (Potts et al., 2000; Agarwal et al., 2003). The evaluation of inflammatory process and damage to sperm DNA of rats exposed to NBLCO and how such damages can be ameliorated by co-administration of ethanol leaf-extract of Ageratum conyzoides was the focus of this study.

\section{MATERIALS AND METHODS:}

The crude petroleum used in this study was obtained from the Nigerian National Petroleum Corporation (NNPC) Laboratory, Port Harcourt, Nigeria. The whole plant was obtained from the Botanical farm of the Department of Pharmacognosy and Natural Medicine, University of Uyo, Nigeria. Specimen of the leaves was authenticated by an expert in the Department of Botany and Ecological Studies, University of Uyo. A voucher specimen (UUH 3517) was deposited at the Herbarium.

\subsection{Preparation of leave extract:}

The leaves of $A$. conyzoides were rinsed with distilled water and dried under shade. The dried leaves were ground into powder with an electric blender. Four hundred grams of the blended leaves sample was macerated in $700 \mathrm{~mL} 70 \%$ ethanol agitated for 10 minutes with an electric blender and left overnight in a refrigerator at $4^{\circ} \mathrm{C}$. The mixture was filtered with a cheese cloth and the filtrate obtained concentrated under reduced pressure using a rotary evaporator $\left(\right.$ at $37^{\circ} \mathrm{C}$ ) to about $10 \%$ of its original volume. The 
concentrate was then allowed in a water bath at $37^{\circ} \mathrm{C}$ for complete evaporation to dryness yielding $40.64 \mathrm{~g}(10.16 \%)$ of the extract.

\subsection{Acute toxicity test:}

Acute toxicity study (LD50) was estimated using Lorke's method [16] (Lorke, 1993). A total of 25 mice weighing between 15 and $22 \mathrm{~g}$ were divided into five groups with five mice per group. Mice in the five groups were respectively administered $3000 \mathrm{mg} / \mathrm{kg}, 3500 \mathrm{mg} / \mathrm{kg}, 4000 \mathrm{mg} / \mathrm{kg}, 4500$ $\mathrm{mg} / \mathrm{kg}$ and $5000 \mathrm{mg} / \mathrm{kg}$ of body weight intraperitoneally. All experimental animals were observed for physical signs of toxicity such as gasping, palpitation, writhing, decreased respiratory rate, body limb and death after 24 hours. The median lethal dose of Ageratum conyzoides was calculated as geometrical means of the maximum (most tolerable) dose producing $0 \%$ mortality (a) and the minimum (least tolerable) dose producing $100 \%$ mortality (b) using the formula:

$\mathrm{LD} 50=\sqrt{ } \mathrm{ab}$

$\mathrm{LD} 50=\sqrt{ } 3500 \times 4000$

$=3741.66 \mathrm{mg} / \mathrm{kg}$.

The acute toxicity test for the NBLCO also involved 25 mice weighing between 15 and $22 \mathrm{~g}$ were divided into five groups with five mice per group. Mice in the five groups were administered intraperitoneally $10 \mathrm{~mL} / \mathrm{kg}, 15 \mathrm{~mL} / \mathrm{kg}$, $20 \mathrm{~mL} / \mathrm{kg}, 25 \mathrm{~mL} / \mathrm{kg}$ and $30 \mathrm{~mL} / \mathrm{kg}$ of body weight respectively.

$$
\mathrm{LD} 50=\sqrt{ } 10 \times 20
$$$$
=14.14 \mathrm{~mL} / \mathrm{kg} \text {. }
$$

\subsection{Experimental design and treatment of animals:} Forty male Wistar rats (119-128 g body weight) were obtained from the Animal House of the Faculty of Basic Medical Sciences University of Uyo, Nigeria and were kept in a well-ventilated section of the Animal House. They were allowed access to feed (Chow: vital feeds, Grand Cereals Ltd, Jos) and water ad libitum. The animals were kept in separate experimental room and allowed to acclimatize for a period of one week before commencement of studies.

The rats were randomly divided into eight groups (I-VIII) of five rats each. The rats in group I served as the control and were oral gavaged $3 \mathrm{~mL} / \mathrm{kg}$ of normal saline; groups II-IV gavaged $374.17 \mathrm{mg} / \mathrm{kg}, 748.33 \mathrm{mg} / \mathrm{kg}$ and 1122.50 $\mathrm{mg} / \mathrm{kg}$ body weight of the extract of $A$. conyzoides as low, medium and high doses, respectively, which were calculated as $10 \%, 20 \%$ and $30 \%$ of the $\mathrm{LD}_{50}(3741.66 \mathrm{mg} / \mathrm{kg})$ respectively. Group V was gavaged $3 \mathrm{~mL} / \mathrm{kg}$ body weight of NBLCO; this dose was calculated as $20 \%$ of the lethal dose of $14.14 \mathrm{~mL} / \mathrm{kg}$. Groups VI-VIII animals were administered the aforementioned doses of the extract of $A$. conyzoides and $3 \mathrm{~mL} / \mathrm{kg}$ body weight of NBLCO respectively. In all cases, doses were applied daily for 31 days according to animal's most recent body weight. The experimental procedures involving the animals and their care were conducted in conformity with the approved guidelines by the Research and Ethical Committee of the Faculty of Basic Medical Sciences, University of Uyo, Nigeria.

\subsection{Collection of blood sample for analysis:}

After the thirty one (31) days of administration, the rats were anaesthetized with chloroform soaked in swap of cotton wool in a killing chamber. Blood was collected by cardiac puncture with a $5 \mathrm{~mL}$ sterile syringe and needle. The total volume of blood collected was $3.5 \mathrm{~mL}$, which was transferred into plain sample bottles. This was allowed to stand to clot after which the serum was separated by centrifugation (RM12 micro centrifuge, REMI, England) at $3000 \mathrm{rpm}$ for 10 minutes at $25^{\circ} \mathrm{C}$. The serum obtained was stored at $-20^{\circ} \mathrm{C}$ until required for analysis.

\subsection{Damaged DNA Assay (8-Hydroxy- desoxyguanosine (8-OHdG) :}

The 8-OHdG level was estimated in sperm DNA. The quantification of $\mathbf{8 - O H d G}$ was carried out following the prescribed protocol by the manufacturer. This was achieved by using Cayman's kit according to method describe by Tamburrino and co-workers [17] (Tamburrino et al., 2012).

\subsection{C - reactive protein assay:}

Serum C-reactive protein level was determined by the latex agglutination method Singer JM, Plotz CM, Elster SK (1951) The Latex-Fixation Test III. Agglutination Test for $\mathrm{C}$ - reactive protein and Comparison with the Capillary Precipitin Method. American Journal of Clinical Pathology, 28, 611-617. [18] [19] (Singer et al., 1951; Hokoma and Nakamura, 1987). This was done using Biosystems C-reactive protein latex from Spain.

\subsection{Interlukin-6 assay:}

The assay was performed at room temperature $\left(18-25^{\circ} \mathrm{C}\right)$. The Sandwich-ELISA method was adopted as all reagents, working standards and samples were prepared according to the manufacturer's instructions.. The optical density (OD) was measured spectrophotometrically using microplate reader at a wavelength of $450 \mathrm{~nm}$.

\subsection{Determination of total white blood cells and platelets:}

The blood sample in the EDTA sample bottles were used for the determination of total white blood cell, neutrophil and platelets with the aid of an automatic haematology analyzer (Mindray Hematology analyzer, BC-2300).

\subsection{Statistical analysis:}

Data were expressed as the mean \pm standard error of the mean. Statistical analysis was carried out using window SPSS package (SPSS 22.00 version). Data were analyzed using one way analysis of variance (ANOVA), results obtained were further subjected to test for least significant difference (LSD). Values of $\mathrm{P}<0.05$ were considered significant. 


\section{Anti-Inflammation Potentials of Ageratum Conyzoides against Crude Oil-Induced Inflammation and Sperm DNA Damage in Male Wistar Rats

\section{RESULTS:}

The results of spermatozoa DNA damage following Nigerian Bonnylight crude oil and Ageratum conyzoides treatments

The results obtained following the administration of Nigerian Bonny light crude oil (NBLCO) and coadministration of leaf extracts of Ageratum conyzoides are presented in figures 1 and 2. The results of the study showed that administration of NBLCO significantly damage spermatozoa DNA with respect to the control group $(\mathrm{p}<0.05)$ while co-administration of ethanolic leaf extracts of $A$. conyzoides to groups VI-VIII significantly reduce such damage in a dose-dependent fashion $(\mathrm{p}<0.05)$.

The results of the inflammation biomarkers following administration of Nigerian Bonnylight crude oil and Ageratum conyzoides.

The mean values for C-reactive protein $(\mathrm{mg} / \mathrm{L})$ and interleukin-6 $(\mathrm{pg} / \mathrm{mL})$ obtained in this study are shown in table 1 . The results of the study showed that administration of NBLCO significantly increase CRP and interleukin-6 (IL6 ) levels with respect to groups I-IV group $(\mathrm{p}<0.05)$ while co-administration of ethanolic leaf extracts of A. conyzoides to groups VI-VIII significantly reduce CRP and interleukin6 in a dose-dependent fashion $(\mathrm{p}<0.05)$.

The results of the platelets, total white blood cells and neutrophils following administration of Nigerian Bonnylight crude oil and Ageratum conyzoides.

The mean values for platelets $\left(10^{9} / \mathrm{L}\right)$, total white blood cells $\left(10^{9} / \mathrm{L}\right)$ and neutrophils $(\%)$ in this study are shown in table 2 . The results of this study showed that administration of NBLCO significantlyreduce platelet count and the percentage of neutrophil but significantly increase total white blood cells with respect to the control group $(\mathrm{p}<0.05)$. While co-administration of ethanolic leaf extracts of $A$. conyzoides to groups VI-VIII significantly increase platelets and neutrophils and reduce white blood cells significantly $(\mathrm{p}<0.05)$.

Legend: $\mathrm{a}, \mathrm{b}, \mathrm{c}$ and $\mathrm{d}=$ significantly different from groups I, II, III and IV respectively at $(\mathrm{p}<0.05)$

Table 1. The mean platelets, total white cell and neutrophil after NBLCO and co-administration of varied doses of ethanol leave extract of Ageratum conyzoides.

\begin{tabular}{llll}
\hline Groups & $\begin{array}{l}\text { Platelet } \\
(109 / \mathrm{L})\end{array}$ & $\begin{array}{l}\text { WBC } \\
(109 / \mathrm{L})\end{array}$ & $\begin{array}{l}\text { Neutrophil } \\
(\%)\end{array}$ \\
$\mathrm{V}(\mathrm{NBLCO})$ & $436.40 \pm$ & $11.40 \pm$ & $32.60 \pm$ \\
& 0.68 & 0.70 & 0.51 \\
$\mathrm{VI}(\mathrm{NBLCO}+$ & $544.80 \pm$ & $8.84 \pm$ & $33.40 \pm$ \\
$\mathrm{LDE})$ & $0.97 \mathrm{e}$ & $0.15 \mathrm{e}$ & 0.68 \\
VII (NBLCO + & $645.00 \pm$ & $7.86 \pm$ & $43.40 \pm$ \\
$\mathrm{MDE})$ & $0.45 \mathrm{e}, \mathrm{f}$ & $0.04 \mathrm{e}$ & $0.24 \mathrm{e}, \mathrm{f}$ \\
VIII (NBLCO + & $680.25 \pm$ & $7.70 \pm$ & $41.75 \pm$ \\
$\mathrm{HDE})$ & $0.63 \mathrm{e}, \mathrm{f}, \mathrm{g}$ & $0.15 \mathrm{e}, \mathrm{f}$ & $0.85 \mathrm{e}, \mathrm{f}$ \\
\hline
\end{tabular}

Legend: $\mathrm{e}, \mathrm{f}$, and $\mathrm{g}=$ significantly different from groups $\mathrm{V}$, VI and VII respectively at $(\mathrm{p}<0.05)$

\section{DISCUSSION:}

The anti-inflammation capacity of Ageratum conyzoides against crude oil-induced inflammation and sperm DNA damage in male Wistar rats has been demonstrated in this study. The administration of NBLCO cause a significantly increase white blood cell (WBC) counts and induced high inflammatory activities in semen of rats which were reversed by co-administration of ethanol extract of Ageratum conyzoides. The high value of $\mathrm{WBC}$ in the semen recorded in this study could be linked to the leakage of WBC from the site of inflammation due to the unmitigated increase in permeability of blood vessels feeding the testis. This leakage may have allowed WBC to migrate out of the blood vessels to interact with the vascular endothelium where inflammatory process is further amplified and escalated. This observation agrees with similar report in literature on human, where an abnormal presence of leukocytes in human semen has been suggested to indicate genital tract inflammation [20] (Anderson, 1995). It was also observed that NBLCO administration caused significant sperm DNA damage and inflammation, which is indicated by the significantly high concentrations of C-reactive protein and interleukin 6 (IL-6) in the seminal plasma.

The damaging effect of NBLCO to spermatogenesis and sperm function seems to be mediated by inflammation in addition to the already established oxidation mechanism as evidently demonstrated in this study indicates that the possible intervention protocol will include the augmentation of the scavenging capacity of the antioxidants in seminal plasma. A natural occurring pool of antioxidants such as Ageratum conyzoides become an acceptable choice. Ageratum conyzoides is very rich in antioxidants with capacity to quench or reduce oxidative stress and lipid peroxidation to the barest minimum in semen [13] (Ita et al., 2018). The plant contains flavonoids, such as quercetin which has been reported to account for its anti-inflammatory effect; this has been demonstrated to inhibit the $\beta$-glucuronidase from human polymorphonuclear leukocytes [21] [22] (Lee et al., 1982; Busse et al., 1984). Since inflammation is a complex process involving recruitment and activation of neutrophils, lymphocytes, macrophages and other cells with a coordinated activity of cytokines, Ageratum conyzoides with its flavonoids content has been demonstrated in this study to evidently mitigate crude oil-induced inflammatory activities. The negative impact of crude oil on the body can include wide spectrum of pathologic conditions from inflammatory effects on organs to potential damage to the DNA. Important chemicals of inflammation are the cytokines, the cytokines have their physiological roles that impact on the quality of semen and male fertility, and this is however dependent upon their concentrations as high levels of certain cytokines in semen are often associated with poor quality of semen parameters Naz RK, Evans L (1998). Presence and modulation of interleukin-12 in seminal plasma of fertile and infertile men. J Androl., 19(3):302-307 [23] (Naz and Evans, 1998).

The integrity of genomic sperm DNA is crucial to the male reproductive health in its entire ramification as damage to DNA by NBLCO as demonstrated in this study 


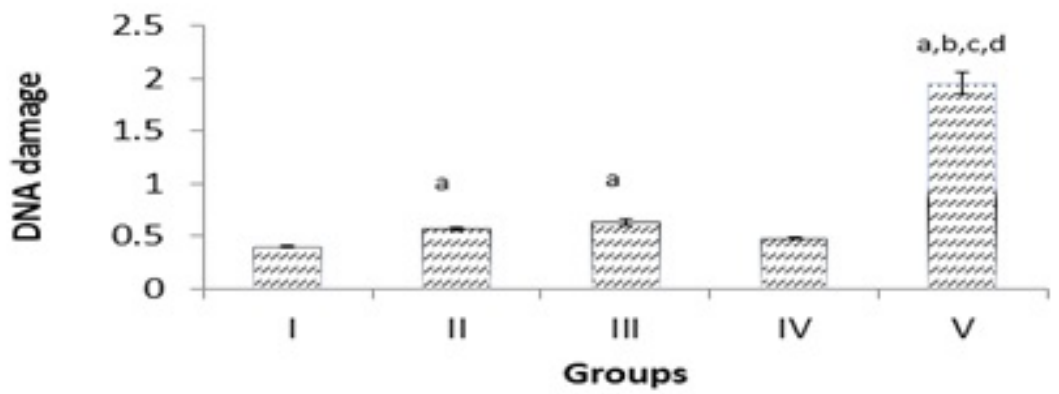

Fig. 1: Comparing DNA damage between the control, low, medium and high doses of ethanol leave extract of A. conyzoides and NBLCO.

$\mathrm{a}=$ versus group $\mathrm{I}, \mathrm{b}=$ versus group $\mathrm{II}, \mathrm{c}=$ versus group III, $\mathrm{d}=$ versus group IV at $\mathrm{p}<0.05$.

Figure 1.

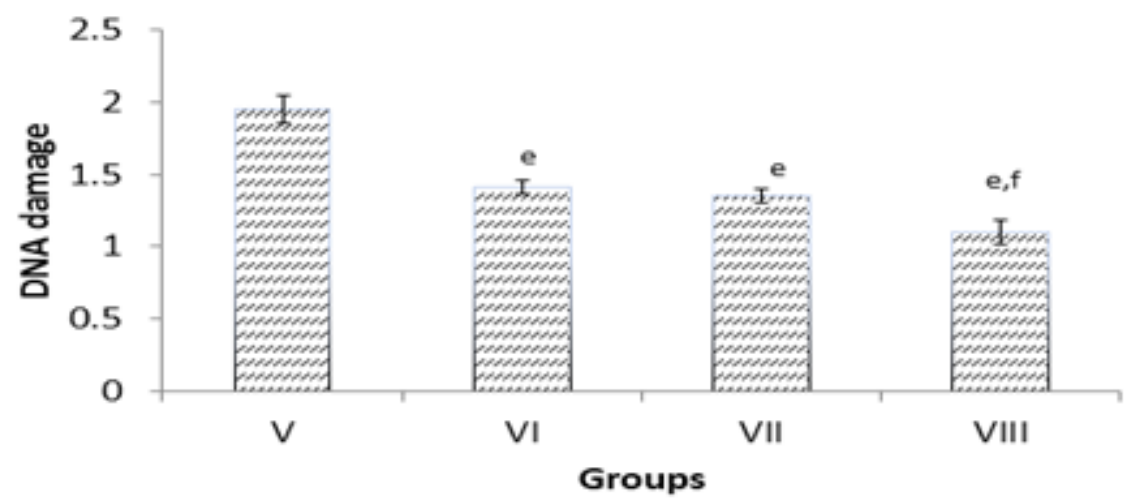

Figure 2: Comparing DNA damage in NBLCO group with groups co-administered varied doses of ethanol leave extract of A. conyzoides.

$\mathrm{e}=$ versus group $\mathrm{V}, \mathrm{f}=$ versus group $\mathrm{VI}, \mathrm{g}=$ versus group $\mathrm{VII}$ at p $<0.05$.

Figure 2.

can have various negative consequences. The sperm DNA is usually protected by its compact organization and natural antioxidant defense systems within the seminal plasma. In the light of the foregoing, efforts to prevent excessive generation of ROS and lipid peroxidation by antioxidant defense mechanism will ultimately prevent inflammation particularly the chronic type and therefore ameliorate further damages to the spermatozoa DNA. This inference seems to concur the fact that innate antioxidant defense within the seminal plasma is very important for the protection of the spermatozoa from free radical attack [24] (Aitken et al., 2014). The plant, Ageratum conyzoides avail a complementary advantage to the endogenous antioxidant strength. Its ethanol leave-extract co-administration with NBLCO has been demonstrated in this study to mitigate the inflammation induced by NBLCO evidently by complete reversal of damage to the sperm DNA, C-reactive protein, IL-6 and WBC count to tolerable levels.

It is concluded that the NBLCO impact negatively on spermatozoa by induction of inflammation with an escalated sperm DNA damage that can be prevented by the administration of ethanol leaf-extract of Ageratum conyzoides.

\section{REFERENCES}

[1] Colborn T. Vom Saal FS, Soto AM. Environ Health Perspect. 1993;101:378-384. 


\section{Anti-Inflammation Potentials of Ageratum Conyzoides against Crude Oil-Induced Inflammation and Sperm DNA Damage in Male Wistar Rats

[2] Evans HJ. Mutation and mutagenesis in inherited and acquired human disease. Mutat Res. 1996;351:89-103.

[3] Morris ID. The spectrum of DNA damage in human sperm assessed by single cell gel electrophoresis (Comet assay) and its relationship to fertilization and embryo development. vol. 17. Hum Reprod; 2002

[4] Evenson DP, Larson KL, Jost LK. Sperm chromatin structure assay: its clinical use for detecting sperm; 2002. DNA fragmentation in male infertility and comparisons with other techniques. J Androl., 23:25-43.

[5] Lyons R, Temple J, Fone D. Acute health effects of the sea oil spill. Journal of Epidemiology and Community Health. 1999;53:306-310.

[6] Izegbu M, Ojo M, Shittu L. Clinical -pathological pattern of testicular malignancies. vol. 1; 2005.

[7] Shittu L, Bankole M, Oguntola J, Ajala O, Shittu R, Ogundipe O. Bankole M, Ahmed T, Ashiru O. Scientific Research and Essays. 2007;2(8):319-324.

[8] Shittu L, Shittu R, Ajala M, Bankole M, Benebo A. Adesite S, Tayo A, Ashiru O. International Journal of Morphology. 2008;26(3):643-652.

[9] Nwaokwoala R, George W. Recovery of rats from the effects of prolonged exposure to Nigeria crude oil, West Africa society Pharmacology; 2000.

[10] Yadau J, Seth N. Cytogenetical Damage in Petrol Pump Workers. IJHG; 2001.

[11] Anderson D, Yu TW, Browne MA. The use of the same image analysis system to detect genetic damage in human lymphocytes treated with doxorubicinin the Comet and fluorescence in situ hybridization (FISH) assay. Mutat Res. 1997;390:69-77.

[12] Detection of benzo(a)pyrene diolepoxide-DNA adducts in sperm of men exposed to cigarette smoke. vol. 72. Fertil Steril; 1999. p. 330-335.

[13] Ita SO, Effiong EF, Okon MS, Robert AS, Francis UE. Impact of Crude Oil-induced Oxidative Stress and Lipid Peroxidation on Spermatogenesis: The Anti-Oxidative Role of Ageratum conyzoides. J Reproductive Endocrinol \& Infert. 2018;1:26.

[14] Potts JM, Sharma R, Pasqualotto F, Nelson D, Hall G. Agarwal A (2000). Association of urea plasma urealyticum with abnormal reactive oxygen species levels and absence of leukocytospermia. J Urol;6(1775-1778).

[15] Agarwal A, Said TM. Role of sperm chromatin abnormalities and; 2003. DA damage in male infertility. Hum Reprod., 9:331-345.

[16] Lorke D. A New Approach to Practical Acute Toxicity Testing. Arch Toxicol. 1993;54:275-287.

[17] Tamburrino L, Marchiani S, Montoya M, Marino FE, Natah I. Mechanisms and clinical correlates of sperm DNA damage. Asian J Androl. 2012;14:24-31.

[18] Singer JM, Plotz CM, Elster SK. The Latex-Fixation Test III. Agglutination Test for C - reactive protein and Comparison with the Capillary Precipitin Method. American Journal of Clinical Pathology. 1951;28:611-617.

[19] Hokoma Y, Nakamura RM. C-Reactive Protein: Current Status and Future. Perspectives Journal of Clinical Laboratory Analysis. 1987;1:15-27.

[20] Anderson DJ. should male infertility patients be tested for leukocytospermia?. vol. 63. Fertil Steril; 1995.

[21] Lee TP, Matteliano ML. Middleton Jr. E. 1982;.

[22] Busse WW, Kopp DE. Middleton Jr. E. 1984;73:801-809.

[23] Naz RK, Evans L. Presence and modulation of interleukin12 in seminal plasma of fertile and infertile men. J Androl. 1998;3(302-307).
[24] Aitken RJ, Smith TB, Jobling MS, Baker MA, Iuliis GND. Oxidative stress and male reproductive health. Asian J Androl. 2014;16:31-38. 